University of Nebraska - Lincoln

DigitalCommons@University of Nebraska - Lincoln

2006

\title{
Effects, Transfer, and Fate of RDX from Aged Soil in Plants and Worms
}

\author{
E.P.H. Best \\ US Army Engineer Research and Development Center, Environmental Laboratory, 3909 Halls Ferry Road, \\ Vicksburg, MS 39180, USA \\ K.N. Geter \\ Analytical Services, Inc., 3532 Manor Drive Ste \#3, Vicksburg, MS 39180, USA \\ H.E. Tatem \\ US Army Engineer Research and Development Center, Environmental Laboratory, 3909 Halls Ferry Road, \\ Vicksburg, MS 39180, USA \\ B.K. Lane \\ Analytical Services, Inc., 3532 Manor Drive Ste \#3, Vicksburg, MS 39180, USA
}

Follow this and additional works at: https://digitalcommons.unl.edu/usarmyresearch

Part of the Operations Research, Systems Engineering and Industrial Engineering Commons

Best, E.P.H.; Geter, K.N.; Tatem, H.E.; and Lane, B.K., "Effects, Transfer, and Fate of RDX from Aged Soil in Plants and Worms" (2006). US Army Research. 17.

https://digitalcommons.unl.edu/usarmyresearch/17

This Article is brought to you for free and open access by the U.S. Department of Defense at DigitalCommons@University of Nebraska - Lincoln. It has been accepted for inclusion in US Army Research by an authorized administrator of DigitalCommons@University of Nebraska - Lincoln. 


\title{
Effects, transfer, and fate of RDX from aged soil in plants and worms
}

\author{
E.P.H. Best ${ }^{a, *}$, K.N. Geter ${ }^{b}$, H.E. Tatem ${ }^{a}$, B.K. Lane ${ }^{b}$ \\ ${ }^{a}$ US Army Engineer Research and Development Center, Environmental Laboratory, 3909 Halls Ferry Road, \\ Vicksburg, MS 39180, USA \\ b Analytical Services, Inc., 3532 Manor Drive Ste \#3, Vicksburg, MS 39180, USA
}

Received 9 September 2004; received in revised form 10 May 2005; accepted 21 May 2005

Available online 19 July 2005

\begin{abstract}
The objectives of this study were to provide data that can be used to predict exposure-based effects of RDX in aged soil on multiple endpoint organisms representing two trophic levels. These data can be used for defining criteria or reference values for environmental management and conducting specific risk assessment. Dose-response experiments formed the basis for the evaluation of toxic effects and transfer of contaminants from soil into two trophic levels. Long-term exposure tests were conducted to evaluate chronic, sublethal, toxicity and transfer of aged soil-based explosives, with RDX as main contaminant. In these tests, plants were exposed for 55 days in the greenhouse, biomass was determined and residues of explosives parent compounds and RDX metabolites were analyzed using HPLC techniques. Worms were exposed for 28 days (Eisenia fetida) and 42 days (Enchytraeus crypticus) in the laboratory, biomass and number were determined, and tissues were analyzed for explosives compounds. The plants tolerated concentrations up to $1540 \mathrm{mg} \mathrm{RDX} \mathrm{kg} \mathrm{m}^{-1}$ soil-DW. Biomass of Lolium perenne was not significantly related to soil-RDX concentration, while biomass of Medicago sativa significantly increased. No screening benchmark for RDX in soil for plants was calculated, since concentrations up to $1540 \mathrm{mg} \mathrm{kg}^{-1}$ soil failed to reduce biomass by $20 \%$ as required for a LOEC. RDX, RDX-metabolite MNX, and accompanying HMX concentrations in plants were significantly related to concentrations in soil after 55 days of exposure (RDX: $R^{2}=0.77-0.89$; MNX $R^{2}=0.53-0.77$; HMX: $R^{2}=0.67-0.71$ ). The average bioconcentration factors (BCF) were for RDX 17 in L. perenne and 37 in M. sativa, and for HMX 2 in L. perenne and 44 in $M$. sativa. The worms also tolerated concentrations up to $1540 \mathrm{mg} \mathrm{RDX} \mathrm{kg}^{-1}$ soil-DW. Biomass of E. fetida adults decreased with soil-RDX concentration, and a LOEC of $1253 \mathrm{mg} \mathrm{kg}^{-1}$ soil-DW was estimated. RDX concentrations in E. fetida were significantly related to concentrations in soil after 28 -day exposure $\left(R^{2}=0.88\right)$. The average BCF in E. fetida for RDX was 1 . Because in response to exposure to RDX-contaminated soil the RDX concentrations in plants increased initially and decreased subsequently, while those in worms increased continuously, RDX in worm tissues may accumulate to higher concentrations than in plant tissues, regardless of the low average BCF for worms. (c) 2005 Elsevier Ltd. All rights reserved.
\end{abstract}

Keywords: Explosives; Aged soil; Biotransfer; Lolium; Medicago; Eisenia

\footnotetext{
${ }^{*}$ Corresponding author. Tel.: +1 601634 4246; fax: +1 6016344002.

E-mail address: beste@wes.army.mil (E.P.H. Best).
}

0045-6535/\$ - see front matter (c) 2005 Elsevier Ltd. All rights reserved. doi:10.1016/j.chemosphere.2005.05.039

This article is a U.S. government work, and is not subject to copyright in the United States. 


\section{Introduction}

Explosives, including hexahydro-1,3,5-trinitro-1,3, 5-triazine (RDX), octahydro-1,3,5,7-tetranitro-1,3,5,7tetrazocine (HMX), 2,4,6-trinitroluene (TNT), and associated byproducts and degradation compounds, have been released into the environment from munitions production and processing facilities. Military grades of RDX contain about 10\% HMX. RDX is a persistent chemical in the environment and has been identified at 16 National Priority List for Superfund Cleanup sites across the US (ATSDR, 1995). These sites include US Army Ammunition Plants (AAPs) and load, assembly, and pack (LAP) processing sites. RDX is also present in the environment as a result from decommissioning activities and through field usage and disposal activities such as open burning. RDX has been found in environmental media only in the vicinity of such sites. Explosives-contaminated soil concentrations are extremely heterogeneous, ranging from 0.7 to $74000 \mathrm{mg} \mathrm{kg}^{-1}$ for RDX, and from 0.7 to $5700 \mathrm{mg} \mathrm{kg}^{-1} \mathrm{DW}$ for HMX, and from 0.08 to $87000 \mathrm{mg} \mathrm{kg}^{-1}$ for TNT, respectively (Talmage et al., 1999).

The use of toxicity data is an important tool in predicting the effects of contaminants on populations, defining criteria or reference values for environmental management, and conducting site-specific risk assessment (Renoux et al., 2001; Robidoux et al., 2002a). To determine if concentrations at a site might be harmful to the indigenous species, the maximum measured media-specific concentration can be compared with a criterion or screening benchmark. The criterion or benchmark is a concentration that should not result in adverse ecological effects to the populations of indigenous species. Both, terrestrial plants and invertebrates are important, because they contribute to the functional aspects of the soil, and because of their role in the food chain. For plants and soil invertebrates, lowest- or noobserved effect concentrations (LOECs or NOECs) have to be determined as a basis for these screening benchmarks. In plants often effective concentrations causing a 20\% decrease in biomass, EC20s, are used as a measure for an LOEC. In animals, traditionally concentrations causing 50\% mortality, LC50s, have been used as a measure for toxicity. To date effects-based ecotoxicological criteria for explosives-contaminated soil are extremely scarce. These would be required for safe management of the future use of decommissioned military training sites. Moreover, among the existing test data relating to RDX, concentration-dependent effects of RDX in plants in hydroponics do not compare well with effects in plants on soil, because the characteristics of the matrix differ. Also, effects on plants and worms of RDX spiked onto soil, and of RDX from aged soil are difficult to compare. Spiking can cause solvent effects. The time allowed for evaporation of the solvent prior to incuba- tion can permit a decrease in the concentration of the parent compound and the formation of undefined degradation compounds in the test. In aged soil, other contaminants, such as nitroaromatics and metals, may be present that may confound the RDX effects.

The published screening benchmark for RDX in soil for terrestrial plants is $100 \mathrm{mg} \mathrm{kg}^{-1}$ (Talmage et al., 1999). This value is based on the LOEC of $100 \mathrm{mg}$ RDX kg-1 for aged soil in cucumber (Cucumis sativa; Simini et al., 1995). However, concentrations of up to $3320 \mathrm{mg}$ spiked HMX kg${ }^{-1}$ forest soil failed to decrease emergence and seedling biomass of, respectively, lettuce (Lactuca sativa) and barley (Hordeum vulgare; Robidoux et al., 2003). No screening benchmark for RDX in soil for soil invertebrates has been published (Talmage et al., 1999). Concentrations of $500 \mathrm{mg} \mathrm{RDX} \mathrm{kg}^{-1}$ spiked on artificial soil reduced earthworm (Eisenia fetida) biomass, but by less than 20\% (Phillips et al., 1993). A concentration of $711 \mathrm{mg}^{2}$ spiked $\mathrm{HMX} \mathrm{kg}^{-1}$ soil did not significantly reduce E. Andrei biomass (Robidoux et al., 2002b).

RDX can be taken up by plants, is translocated to stems and leaves, and usually accumulates in leaves. Metabolism of RDX by the plant is negligible (Harvey et al., 1991; Best et al., 1999). Uptake from aqueous solutions is far higher than uptake from soil, and uptake during short-term exposure is higher than during longterm exposure (Harvey et al., 1991; Price et al., 2002). RDX is slowly but extensively absorbed following ingestion by animals (McNamara et al., 1974). Entry of RDX into worm tissues from dermal contact, and subsequent accumulation has not been documented yet, as far as we know.

Our present study aims at providing data that can be used to predict the exposure-based effects of RDX in aged soil on multiple endpoint organisms representing two trophic levels. These data can be utilized to define criteria or reference values for environmental management and conducting specific risk assessment. Dose-response experiments formed the basis for the evaluation of toxic effects and transfer of contaminants from soil into two trophic levels.

\section{Materials and methods}

\subsection{Experimental}

A sublethal, chronic toxicity test was carried out to evaluate the effects and transfer of RDX contamination from aged soil on the test organisms. Dose-response curves for RDX concentrations between 0 and $1540 \mathrm{mg} \mathrm{kg}^{-1} \mathrm{DW}$ were constructed for both plant and animal tests. The concentration of $1540 \mathrm{mg} \mathrm{RDX} \mathrm{kg}{ }^{-1}$ DW was considered high enough to cause a decrease in biomass in both plants and worms, since some plant 
and worm species died at RDX concentrations around $660 \mathrm{mg} \mathrm{kg}^{-1}$ in tests published by others (Phillips et al., 1993; Price et al., 2002), while our test organisms survived short-term exposures. The test mixtures were prepared by mixing RDX-contaminated soil originating from Picatinny, New Jersey, with clean reference soil from the Nebraska Ordnance Plant (NOP), Nebraska (Table 1; Best et al., 2004a,b). The RDX-contaminated soils were excavated from Area L, grid locations 162 GR-F4 (high-RDX) and 162 GR-E5 (low-RDX; Shaw Environmental, 2003). Control potting soil served as a test to verify plant performance, and control OECD soil (OECD, 1984) to verify worm performance. All treatments were replicated five times, and followed a randomized block design. Plant and worm studies included each a total of 50 test units $(1$ reference $\times 2$ species $\times 5$ replicates $)+(4$ RDX treatments $\times 2$ species $\times 5$ replicates). Plant and worm studies included each a total of 10 control units $(1$ control $\times 2$ species $\times 5$ replicates). The following responses were measured. In plants (1) toxicity, as plant biomass formed in 55 days $\left(\mathrm{g} \mathrm{DW} \mathrm{m}^{-2}\right)$, and (2) accumulation, as plant tissue-explosives concentrations accumulated in 55 days ( $\mathrm{mg} \mathrm{kg}^{-1} \mathrm{DW}$ ). In worms (1) toxicity in E. fetida, as biomass (g DW cylinder ${ }^{-1}$ ) and number of adults after 28 days, toxicity in E. crypticus, as number of juveniles after 42 days; and (2) accumulation, as E. fetida tissueexplosives concentrations accumulated in 28 days ( $\mathrm{mg} \mathrm{kg}^{-1} \mathrm{DW}$ ). The three soils were spread and dried in the greenhouse to reach a moisture content of 5$10 \%$. The explosives-contaminated soil was crushed and thoroughly mixed. The reference soil was ground to pass a $2 \mathrm{~mm}$ sieve.

\subsection{Test organisms}

Two plant species were selected for the tests based on their worldwide use and general acceptance in standard test procedures (USEPA, 1996, 1999; ASTM, 1999). The monocotyledonous Lolium perenne (perennial ryegrass) and dicotyledonous Medicago sativa (alfalfa) both have a wide geographical distribution, rapid growth, and profuse generative reproduction. In addition, their seeds germinate simultaneously within several days and the species can be cultivated in the testing environment. Both species are relatively insensitive towards organic contaminants and widely used as a response and bioaccumulating indicator for organics contamination of soils (ICF, 1989; Gorsuch et al., 1990; Malmberg et al., 1998; Van de Leemkuile et al., 1998). Both plant species are

Table 1

Characteristics of the soils used to create the test mixtures and controls

\begin{tabular}{|c|c|c|c|c|c|}
\hline \multirow[t]{2}{*}{ Characteristic } & \multicolumn{5}{|l|}{ Soil } \\
\hline & $\begin{array}{l}\text { Picatinny } \\
\text { high-RDX }\end{array}$ & $\begin{array}{l}\text { Picatinny } \\
\text { low-RDX }\end{array}$ & $\begin{array}{l}\text { Nebraska } \\
\text { ordnance } \\
\text { plant } \\
\text { reference }\end{array}$ & $\begin{array}{l}\text { Plant } \\
\text { control }^{\mathrm{a}}\end{array}$ & $\begin{array}{l}\text { Worm } \\
\text { control }^{\mathrm{a}}\end{array}$ \\
\hline \multicolumn{6}{|c|}{$\overline{\text { Explosives }\left(m g \mathrm{~kg}^{-1} \mathrm{DW}\right)}$} \\
\hline RDX & $1540.5 \pm 393.3$ & $13.8 \pm 6.6$ & $<3.122$ & ND & ND \\
\hline HMX & $41.0 \pm 10.8$ & $0.14 \pm 0.1$ & $<1.913$ & ND & ND \\
\hline $1,3 \mathrm{DNB}$ & $8.5 \pm 2.7$ & $<3.10$ & & & \\
\hline \multicolumn{6}{|l|}{ Organics $\left(m g \mathrm{~kg}^{-1} \mathrm{DW}\right)$} \\
\hline Arochlor-1260 & $7.2 \pm 0.3$ & ND & ND & ND & ND \\
\hline \multicolumn{6}{|l|}{ Nutrients $\left(m g \mathrm{~kg}^{-1} \mathrm{DW}\right)$} \\
\hline Nitrate-N & ND & ND & $117.93 \pm 15.71$ & $122.6 \pm 26.1$ & 3.93 \\
\hline Infinite-sink $\mathrm{P}$ & $4.5 \pm 0.7$ & $18.2 \pm 19.4$ & $0.98 \pm 0.24$ & $14.3 \pm 9.8$ & $0.6 \pm 0.05$ \\
\hline Total-K & ND & ND & 1339 & ND & $5.3 \pm 1.2$ \\
\hline \multicolumn{6}{|l|}{ Other } \\
\hline $\mathrm{pH}_{\text {water }}$ & $5.50 \pm 0.13$ & $6.25 \pm 0.23$ & $6.51 \pm 0.04$ & 5.79 & $7.06 \pm 0.08$ \\
\hline OM (\%DW) & $28.13 \pm 0.61$ & $6.34 \pm 0.56$ & $5.22 \pm 0.06$ & 76.29 & $1.33 \pm 0.16$ \\
\hline TOC (\%DW) & $11.1 \pm 1.3$ & $5.1 \pm 0.3$ & $2.9+0.1$ & ND & ND \\
\hline CEC (meq/100 g DW) & $73.3 \pm 1.6$ & $54.2 \pm 1.6$ & $53.9+5.3$ & ND & ND \\
\hline DW (\%FW) & $81.69 \pm 0.35$ & $88.64 \pm 0.47$ & $90.55 \pm 0.15$ & 41.8 & $99.6 \pm 0.24$ \\
\hline $\mathrm{BD}\left(\mathrm{g} \mathrm{DW} \mathrm{ml}^{-1}\right)$ & $0.75 \pm 0.05$ & $1.25 \pm 0.10$ & $2.17 \pm 0.22$ & 9.3 & $2.39 \pm 0.25$ \\
\hline
\end{tabular}

Mean values and standard deviations ( $N=5$ for explosives, $N=3$ for other characteristics). The levels of 2ADNT, 4ADNT, 2,4DANT, 2,6DANT, 2NT, 3NT, 4NT, 2,4DNT, and 2,6DNT were below detection.

BD: bulk density; OM: organic matter; ND: not determined; TOC: total organic carbon; CEC: cation exchange capacity.

${ }^{a}$ These soils were not subjected to explosives and organics analyses since no prior history of exposure existed. 
considered as moderately ecologically relevant test species, and L. perenne as highly standardized (Markwiese et al., 2000).

Two worm species were selected, also based on their worldwide use in standard test procedures, facilitating comparison with bioaccumulation and toxicity data of other sites, and ease of culture under laboratory conditions. The earthworm Eisenia fetida and the enchytraeid worm Enchytraeus crypticus. Both worm species are suitable bioaccumulation and response indicators for metals as well as organics, and relatively insensitive (ASTM, 1998; Kula and Larink, 1998; Lokke and Van Gestel, 1998). Eisenia species are of low ecological relevance and are highly standardized; enchytraeid worms are highly ecologically relevant and moderately standardized test species (Markwiese et al., 2000).

\subsection{Plant exposure}

Seeds of Lolium perenne var. Linn and Medicago sativa var. Ladack were purchased from the Granite Seed Company, Lehi, UT. For each L. perenne unit, $0.230 \mathrm{~g}$ seeds (200) were weighed and placed on top of 11 $(1580 \mathrm{~g} \mathrm{FW})$ of the appropriate soil mixture contained in 2-1 plastic pots. For each $M$. sativa unit, $0.201 \mathrm{~g}$ seeds were seeded. Plants were cultivated in a greenhouse at the Waterways Experiment Station, Vicksburg, grounds. Irradiance and temperatures followed ambient conditions during the period 18 May-12 July 2002. The pots were watered daily with reverse osmosis (RO) water to maintain the soil at a moisture level of $36 \%$ (field capacity was $38 \%$ ). A moisture level at field capacity allows maximum specific mass transport of contaminants with soil solution. Plants were amended with slow-release Osmocote fertilizer 10 days after onset of the experiment to attain target levels of $352 \mathrm{~kg} \mathrm{~N} \mathrm{ha}^{-1}, 59.2 \mathrm{~kg} \mathrm{P} \mathrm{ha}^{-1}$ and $331.9 \mathrm{~kg} \mathrm{~K} \mathrm{ha}^{-1}$, commonly used for pastures (Best and Jacobs, 2001). They were harvested after 55 days of cultivation. Seeds germinated synchronously, as was verified before the onset of the tests.

\subsection{Worm exposure}

Adult E. fetida specimens were taken from the ERDC laboratory culture, originally purchased from Carolina Biological Supply Company, Burlington, NC. Adult Enchytraeus crypticus specimens were taken from an ERDC laboratory culture reared from a mass culture obtained from R. Kuperman (US Army Aberdeen Proving Ground, MD) in 2001. Food for both worm species was supplied regularly as needed. It was composed of rolled oats, purchased locally, and powered earthworm food purchased from Magic Products Inc., Amherst Junction, WI. For E. fetida, 10 worms were placed on top of $100 \mathrm{~g} \mathrm{FW}$ of the appropriate soil mixture contained in a 250-ml glass Mason-jar. Animals were culti- vated under continuous fluorescent illumination at $20^{\circ} \mathrm{C}$ (ASTM, 1998). For En. crypticus, 10 worms were placed on top of $2 \mathrm{~g} \mathrm{FW}$ of the appropriate soil mixture contained in a 5-ml Petri-dish. Animals were cultivated in darkness at $16^{\circ} \mathrm{C}$. After 28 days adults were removed. All units were moistened regularly with RO water.

\subsection{Sample processing}

After incubation, plants and worms were harvested, and freed from dust and soil particles by rinsing with RO water. Eisenia fetida worms were purged. After collecting, weighing, washing, purging, and re-weighing were completed, plant and worm tissues were placed in plastic Ziploc bags and frozen at $-80{ }^{\circ} \mathrm{C}$. Subsamples were used to determine dry weight. Dry weight (plants and worms) was determined in subsamples by drying the fresh material in a forced-air oven to constant weight $\left(105^{\circ} \mathrm{C}\right)$.

\subsection{Analyses}

Explosives in plant and worm tissues, and in soil were quantified using modifications of method 8330 for soils (USEPA, 1992). Plant and worm extracts were prepared from freeze-dried materials, soil extracts from fresh material. Three replicate samples of each treatment were extracted. Freeze-dried plant and worm tissue aliquots, equivalent to $0.7-\mathrm{g}$ fresh weight $(\mathrm{FW})$, were amended with $0.8-\mathrm{ml}$ acetonitrile in bead-beater vials, and extracted by two successive cycles of 1-min bead-beating at room temperature $\left(22-24^{\circ} \mathrm{C}\right)$ and sonication for $1 \mathrm{~h}$ at $15^{\circ} \mathrm{C}$. All extracts were freed from particles by centrifugation for $10 \mathrm{~min}$ at $2000 \mathrm{~g}$. Supernatants were diluted 1:1 with Millipore-filtered RO water, re-centrifugation, and cleanup. Plant extracts were cleaned up over a 0.5 g Florisil column, worm extracts over a $0.45 \mu \mathrm{m}$ polytetrafluroethylene (PTFE) disk. Each soil mixture was analyzed for explosives, and other chemical and physical characteristics just before incubation. Explosives in soil were determined by extracting a $2-\mathrm{g} \mathrm{FW}$ aliquot in $10-$ $\mathrm{ml}$ acetonitrile by 18 -h sonication at $15^{\circ} \mathrm{C}$, cleanup over a Florisil column, and $10 \times$ concentration. The plant, worm, and soil extracts of the samples in which the highest levels of explosives and metabolites were expected were first screened for the presence of all explosives listed by USEPA Method 8330 (USEPA, 1992). After identifying the explosives in these extracts, only the relevant explosives were determined in all other extracts. The latter compounds were usually: hexahydro-1,3,5-trinitro-1,3,5 triazine (RDX), the RDX-metabolites MNX and/or TNX, and octahydro-1,3,5,7-tetranitro-1,3,5,7tetrazocine (HMX). In the source soil samples 1,3, dinitrobenzene (13DNB) was identified also. Detection limits and recoveries for several target compounds spiked on plants, worms, and soil directly before extraction, varied 
with compound. Method detection levels (MDL) and recoveries were as follows. In freeze-dried plant tissues: MDL was TNT 1.136, 2ADNT 2.016, 4ADNT 2.009, RDX 3.230, MNX 5.454, TNX 0.621, HMX $7.540 \mathrm{mg} \mathrm{kg}^{-1} \mathrm{DW}$; recovery was: TNT 19.3\%, 2ADNT $32.4 \%$, 4ADNT 19.3\%, RDX 71.7\%, MNX 68.6\%, TNX $18.6 \%$, HMX $23.3 \%$. In freeze-dried worm tissues: MDL was TNT 1.174, 2ADNT 1.750, 4ADNT 1.773, RDX 2.176, MNX 3.194, TNX 0.456, HMX $1.645 \mathrm{mg} \mathrm{kg}^{-1}$ DW; recovery was: TNT $80.1 \%$, 2ADNT $88.2 \%$, 4 ADNT $59.9 \%$, RDX $83.9 \%$, MNX $100.4 \%$, TNX $49.5 \%$, HMX $60.1 \%$. In freshly ground soil: MDL was: TNT 1.684, 2ADNT 3.043, 4ADNT 1.225, RDX 3.122, MNX 12.353, TNX 1.195, HMX $1.913 \mathrm{mg} \mathrm{kg}^{-1}$ DW; recovery was: TNT $10.4 \%$, 2ADNT $15.1 \%$, 4ADNT 4.8\%, RDX 99.5\%, MNX 72.6\%, TNX $17.0 \%$, HMX 12.3\%. Details are presented by Best et al. (2004a). Other soil parameters were determined as described by Best et al. (2004a).

\subsection{Data analysis}

Statistical analyses were conducted with the software STATGRAPHICS Plus for Windows Version 32S package (Manugistics, Rockville, MD). Normal distribution of the data was tested using the Shapiro-Wilk's test. Because biomass, and explosives and metabolite concentrations in plant and worm extracts were ln-normally distributed, ln-transformed them prior to analysis of variance (ANOVA) and regression analyses. ANOVA was expanded with a multiple range test using the Fisher's least significant difference procedure. The $p$-value in the ANOVA is a measure of the significance of the analysis; it was set at a 95\% confidence level ( $p$-value of $\leqslant 0.05)$. Linear regression analyses were conducted using the least squares method. Non-linear equations were fitted with the polynomial regression module using the least squares method. For these analyses zero values for tissue explosives levels were replaced by half of the detection levels. The $p$-value in the regression model was set at a $95 \%$ confidence level ( $p$-value of $\leqslant 0.05$ ) unless stated otherwise. The $R^{2}$-value of the regression model indicates the proportion of the variance explained by the model. Regression models explaining at least 50 percent of the variability in the data set, i.e., $R^{2}>0.50$, were considered as meaningful.

\section{Results and discussion}

The explosives concentrations in the five soil mixtures ranged from non-detectable to $1540 \mathrm{mg} \mathrm{RDX} \mathrm{kg}^{-1} \mathrm{DW}$, $41 \mathrm{mg} \mathrm{HMX} \mathrm{kg}{ }^{-1} \mathrm{DW}$, and $8.5 \mathrm{mg} 1,3 \mathrm{DNB} \mathrm{kg}^{-1} \mathrm{DW}$ at the beginning of the incubations (Table 2). The RDX and HMX concentrations were significantly correlated, with correlation coefficients of $\geqslant 98 \%$.

\subsection{Toxicity and bioaccumulation in plants}

Biomass of L. perenne fluctuated, but it was not significantly reduced by soil-RDX concentration up to $1540 \mathrm{mg} \mathrm{kg}^{-1} \mathrm{DW}$ (ANOVA; $p=0.55$ ). This was also apparent from the regression equation fitted to the data (Fig. $1 ; p=0.497, R^{2}=0.02 ;$ ). Other factors apparently

Table 2

Characteristics of the soil mixtures prior to incubation

\begin{tabular}{|c|c|c|c|c|c|}
\hline \multirow[t]{2}{*}{ Characteristic } & \multicolumn{5}{|l|}{ Soil mixtures } \\
\hline & Reference $^{\mathrm{a}}, 0$ & $\mathrm{RDX}^{\mathrm{b}}, 14 \mathrm{mg}$ & $\mathrm{RDX}^{\mathrm{b}}, 645 \mathrm{mg}$ & $\mathrm{RDX}^{\mathrm{b}}, 856 \mathrm{mg}$ & $\mathrm{RDX}^{\mathrm{b}}, 1540 \mathrm{mg}$ \\
\hline \multicolumn{6}{|c|}{$\overline{\text { Explosives }\left(m g \mathrm{~kg}^{-1} \mathrm{DW}\right)}$} \\
\hline RDX & $<3.122$ & $13.8 \pm 6.6$ & $645.0 \pm 41.6$ & $855.5 \pm 88.1$ & $1540.5 \pm 393.3$ \\
\hline HMX & $<1.913$ & $0.14 \pm 0.07$ & $8.6 \pm 0.91$ & $16.9 \pm 1.3$ & $41.0 \pm 10.8$ \\
\hline $1,3 \mathrm{DNB}$ & $<3.100$ & $<3.100$ & $3.59 \pm 0.49$ & $7.25 \pm 0.51$ & $8.5 \pm 2.7$ \\
\hline \multicolumn{6}{|c|}{ Nutrients $\left(m g \mathrm{~kg}^{-1} \mathrm{DW}\right)$} \\
\hline Nitrate-N & $117.93 \pm 15.71$ & ND & ND & ND & ND \\
\hline Infinite-sink $\mathrm{P}$ & $0.98 \pm 0.24$ & $18.2 \pm 19.4$ & $14.3 \pm 5.0$ & $31.6 \pm 15.5$ & $4.5 \pm 0.7$ \\
\hline Total-K & 1339 & ND & ND & ND & ND \\
\hline \multicolumn{6}{|l|}{ Other } \\
\hline $\mathrm{pH}_{\text {water }}$ & $6.51 \pm 0.04$ & $6.25 \pm 0.23$ & $5.80 \pm 0.05$ & $5.25 \pm 0.53$ & $5.50 \pm 0.13$ \\
\hline $\mathrm{OM}(\% \mathrm{DW})$ & $5.22 \pm 0.06$ & $6.34 \pm 0.56$ & $12.51 \pm 0.77$ & $17.28 \pm 0.39$ & $28.13 \pm 0.61$ \\
\hline DW $(\% \mathrm{FW})$ & $90.55 \pm 0.15$ & $88.64 \pm 0.47$ & $86.8 \pm 0.49$ & $85.33 \pm 0.30$ & $81.69 \pm 0.35$ \\
\hline $\mathrm{BD}\left(\mathrm{g} \mathrm{DW} \mathrm{ml}^{-1}\right)$ & $7.17 \pm 0.22$ & $1.25 \pm 0.10$ & $1.10 \pm 0.08$ & $0.99 \pm 0.08$ & $0.75 \pm 0.05$ \\
\hline
\end{tabular}

Mean values and standard deviations ( $N=3$, unless stated otherwise).

BD: bulk density; OM: organic matter; ND: not determined.

${ }^{a}$ Clean NOP soil.

b Target RDX concentrations, in $\mathrm{mg} \mathrm{kg}^{-1} \mathrm{DW}$. 
L. perenne

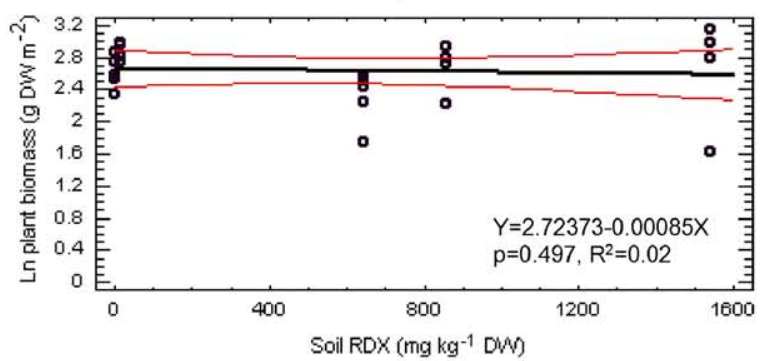

L. perenne

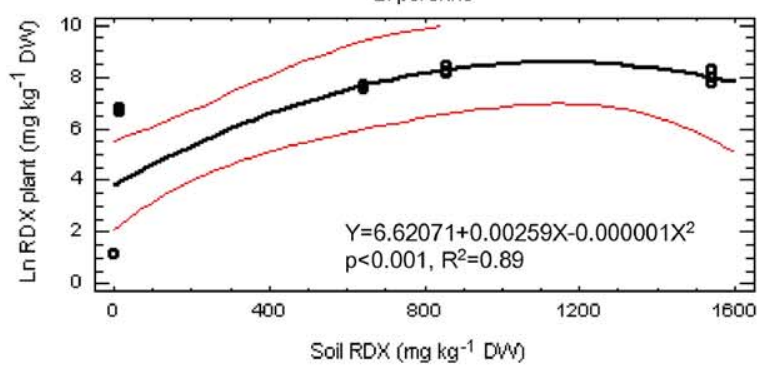

L. perenne

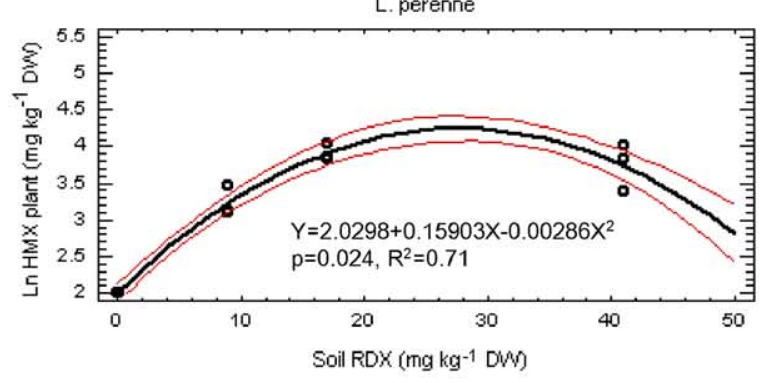

L. perenne

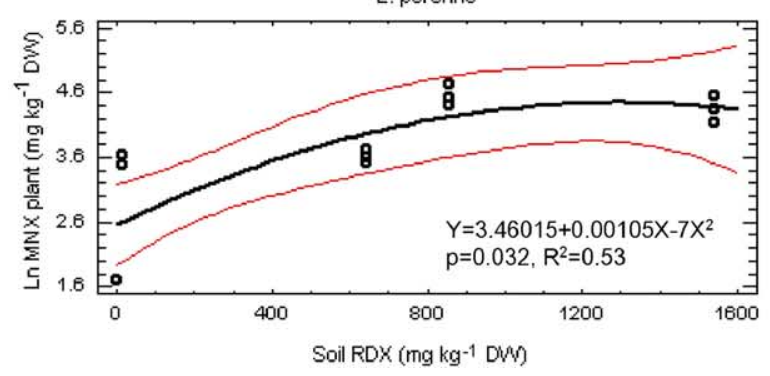

M. sativa
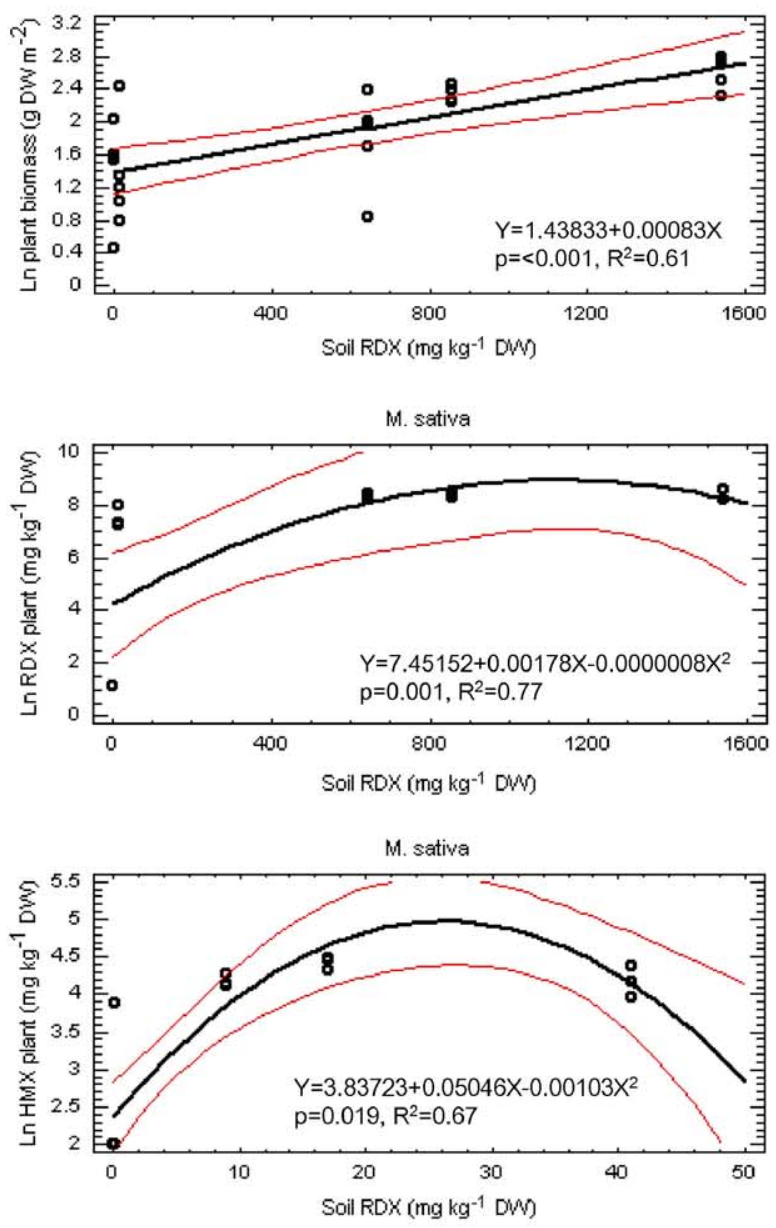

M. Sativa

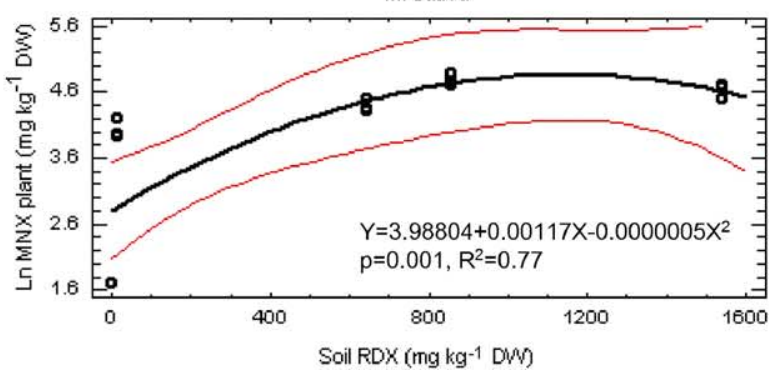

Fig. 1. Relationships between aged explosives concentrations in the soil, and biomass, explosives and metabolite concentrations in plants. Lines represent regression lines and $95 \%$ confidence limits. Regression equation, significance $(p)$, and proportion of variance explained $\left(R^{2}\right)$ by the fitted model indicated.

affected biomass of this species more than soil-RDX concentration. The green color of the shoots turned white, indicating the onset of chlorophyll bleaching 14 days after seeding, and bleaching became more severe later on. In contrast, biomass of $M$. sativa increased significantly with soil-RDX concentration up to $1540 \mathrm{mg} \mathrm{kg}^{-1}$ DW
(ANOVA; $p<0.001$; see also Fig. 1). Overall biomass production of $M$. sativa significantly exceeded that of $L$. perenne (ANOVA; $p<0.001$ ) and bleaching was not visible. Biomass of both plant species on reference soil was similar to that on control soil, confirming that the test soil without contamination supported adequate plant growth. 
Substantial levels of RDX, the RDX-metabolite MNX, and HMX were recovered in the plant tissues. The RDX-metabolite TNX was not detected. Distinction between transformation of RDX by soil microbes and by plants can not be made in the current experimental approach. The ln-transforms of the RDX-, and MNXconcentrations in the plant tissues increased steeply with soil-RDX concentrations up to $856 \mathrm{mg} \mathrm{kg}^{-1} \mathrm{DW}$ and subsequently leveled off. The ln-transforms of the HMX-concentrations in the plant tissues increased also steeply with soil-HMX concentration up to $32 \mathrm{mg} \mathrm{kg}^{-1}$ DW and leveled off thereafter. The polynomial regressions fitted to the ln-transformed tissue explosives levels explained $53-89 \%$ of the variability in the datasets. The following regression equations were fitted to the data and can be used to predict the tissue explosives levels in plants upon exposure to soils contaminated with explosives, in which $Y=$ the ln-transformed tissue explosives concentration (in $\mathrm{mg} \mathrm{kg}^{-1} \mathrm{DW}$ ), and $X=$ the explosives concentration in the soil $\left(\mathrm{mg} \mathrm{kg}^{-1} \mathrm{DW}\right)$. In L. perenne: for soil-RDX concentrations up to a level of $1540 \mathrm{mg} \mathrm{kg}^{-1}, Y=6.6207+0.00259 X-0.000001 X^{2}$, with $Y$ being the tissue-RDX concentration, and $Y=$ $3.46015+0.00105 X-7 X^{2}$, with $Y$ being the tissueMNX concentration; and for soil-HMX concentrations up to a level of $41 \mathrm{mg} \mathrm{kg}^{-1}, Y=2.0298+0.15903 X-$ $0.00286 X^{2}$, with $Y$ being the tissue-HMX concentration (Fig. 1). In $M$. sativa: for soil-RDX concentrations up to a level of $1540 \mathrm{mg} \mathrm{kg}^{-1}, Y=7.45152+0.00178 X-$ $0.0000008 X^{2}$, with $Y$ being the tissue-RDX concentration, and $Y=3.98804+0.00117 X-0.0000005 X^{2}$, with $Y$ being the tissue-MNX concentration; and for soilHMX concentrations up to a level of $41 \mathrm{mg} \mathrm{kg}^{-1}$, $Y=3.83723+0.05046 X-0.00103 X^{2}$, with $Y$ being the tissue-HMX concentration (Fig. 1).

\subsection{Toxicity and bioaccumulation in worms}

Survival of E. fetida after 28-day exposure was usually $80-100 \%$. Exceptions to this rule were four repli- cates with a soil-RDX concentration of $645 \mathrm{mg} \mathrm{kg}^{-1}$ with all worms dead. Worm death in these replicates was attributed to the relatively high moisture content of the soil caused by over-watering rather than the RDX contamination of the soil. There was a significant (ANOVA; $p<0.001$ ) weight loss in worms exposed to soil-RDX concentrations $\geqslant 645 \mathrm{mg} \mathrm{kg}^{-1}$ (Fig. 2). Weight loss was related to increasing soil-RDX concentration, but the linear regression model fitted to the ln-transformed biomass values explained only $35 \%$ of the variability in the dataset. According to the fitted linear regression equation $Y=1.6976-0.00018 X$, in which $Y=\ln$-transformed worm biomass (g DW per cylinder) and $X=$ soil-RDX concentration ( $\mathrm{mg} \mathrm{RDX} \mathrm{kg}{ }^{-1}$ soilDW), a $20 \%$ reduction in worm biomass may occur at a soil-RDX concentration of $1253 \mathrm{mg} \mathrm{kg}^{-1}$. The toxicity was attributed to soil contamination by RDX rather than by HMX, since HMX concentrations $\leqslant 2 \mathrm{mg} \mathrm{kg}^{-1}$ was reported not to affect survival of worms (Robidoux et al., 2002b). RDX, MNX and TNX were recovered in the worm tissues. Tissue explosives levels were generally lower in worms than in plants. The MNX-levels were usually below detection, except when the worms were in an unhealthy state as in the only remaining replicate exposed to $645 \mathrm{mg} \mathrm{kg}^{-1}$ soil-RDX. The TNX-levels were low, but usually detectable. HMX was not detected. As in plants, distinction between transformation of RDX by soil microbes and by worms can not be made in the current experimental approach. The ln-transforms of the RDX-concentrations in the worm tissues increased steeply with soil-RDX concentrations up to $1540 \mathrm{mg} \mathrm{kg}^{-1} \mathrm{DW}$. A linear regression fitted to the $\mathrm{ln}$ transformed tissue RDX levels explained $88 \%$ of the variability in the datasets. Regressions fitted to the other tissue-explosives data were not meaningful, i.e., explained far less than $50 \%$ of the variability. The following regression equation was fitted to the data and can be used to predict the tissue RDX level in E. fetida worms upon exposure to soils contaminated with explosives, in which $Y=$ the $\ln$-transformed tissue RDX concentration (in
E. fetida

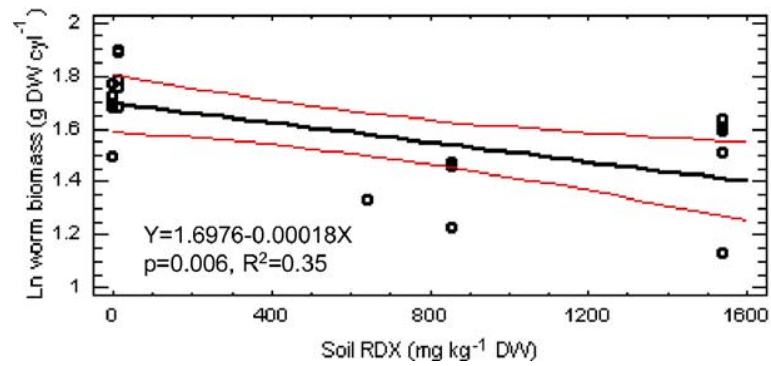

E. fetida

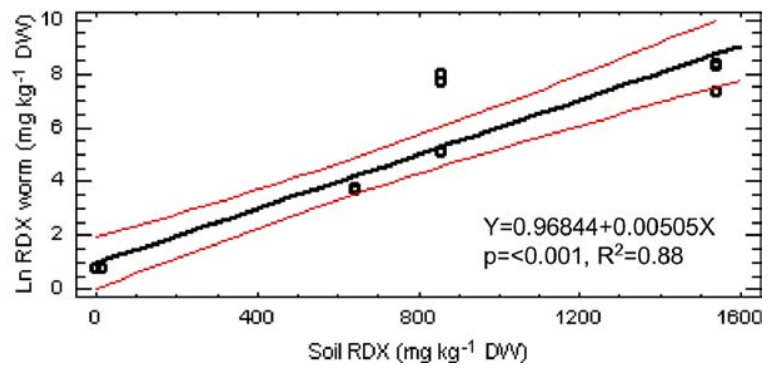

Fig. 2. Relationships between aged explosives concentrations in the soil, and biomass and explosives concentrations in worms. Lines represent regression lines and $95 \%$ confidence limits. Regression equation, significance $(p)$, and proportion of variance explained $\left(R^{2}\right)$ by the fitted model indicated. 
$\left.\mathrm{mg} \mathrm{kg}^{-1} \mathrm{DW}\right)$, and $X=$ the RDX concentration in the soil ( $\mathrm{mg} \mathrm{kg}^{-1} \mathrm{DW}$ ): $Y=0.96844+0.00505 X$ (Fig. 2).

After 42-day exposure, substantial numbers of $E$. crypticus juveniles had developed on all test-soils. Because worm numbers were too high to estimate and worm size was extremely small, no further attempt was made to count the worm numbers. In this case exposure of the worms to the RDX-contaminated test soil did not appear to have a toxic effect.

\subsection{Toxicity screening benchmarks}

The RDX-contaminated, aged, soil mixtures did not cause toxicity responses resulting in a $20 \%$ biomass loss in the exposed plants, and, therefore, no LOEC could be calculated. However, the bleaching effects noted in $L$. perenne may have a biomass-decreasing effect after an exposure period $>55$ days as used in the current tests. This is largely in agreement with the conclusion of Talmage et al. (1999), who indicate that no convincing evidence exists on which LOECs for plants can be based.

However, a LOEC of $1253 \mathrm{mg} \mathrm{RDX} \mathrm{kg}^{-1}$ soil-DW for E. fetida worms was estimated using the linear regression equation fitted to the $1 n$-transformed biomass data. This value is, indeed, far higher than the lower limit of $500 \mathrm{mg} \mathrm{RDX} \mathrm{kg}^{-1}$ soil-DW which did cause $<20 \%$ weight loss, as reported for spiked artificial soil by Will and Suter 1995 (in Talmage et al., 1999).

\subsection{Bioconcentration and biotransfer of explosives}

To predict the effects of contaminants on populations and in food chains, it is important to evaluate the biotransfer of the contaminant as a basis for potential trophic transfer in the ecological groups constituting the food chain. Empirical data on the biotransfer of explosives in lower trophic levels such as plants and worms are extremely scarce, and in the absence of these data ecological risk approaches are based on linear regression equations derived from residues of organics other than explosives in vegetation and beef (Travis and Arms, 1988). The latter approach assumes that the potential of a chemical to accumulate in an organism, i.e. the bio- concentration factor (BCF), is defined as a chemical's concentration in an organism or tissue divided by its concentration in food. The RDX concentrations in plants increased upon exposure to RDX-contaminated soil up to a concentration of $856 \mathrm{mg} \mathrm{kg}^{-1}$, and decreased in response to higher soil concentrations. BCF's in the current study were on average: in plants 17 to 37 for RDX, and 2 to 44 for HMX.

The RDX concentrations in worms increased upon exposure to RDX-contaminated soil up to the highest concentration of $1540 \mathrm{mg} \mathrm{kg}^{-1}$ soil. The BCF for RDX in worms was 1 , potentially indicating that no bioconcentration occurred (Table 3). However, the continued increase in RDX concentration in worm tissues with soil concentrations suggests that RDX concentrations in worm tissues may accumulate to higher concentrations than in plant tissues, regardless of the low average $\mathrm{BCF}$ for worms. The biotransfer factor (BTF) is more useful in risk assessment, since exposure of the organism to the chemical may occur through both food and water pathways. To relate tissue concentrations in the aboveground biomass of vegetation to soil concentrations of a contaminant, the following equation is used (Travis and Arms, 1988): $\log B_{\mathrm{v}}=1.588-0.578 \log$ $K_{\mathrm{OW}}$, in which $B_{\mathrm{v}}$ is the biotransfer factor in herbaceous plant shoots and $K_{\mathrm{OW}}$ is the octanol-water partitioning coefficient of that particular contaminant. Similarly, to relate tissue concentrations in beef to soil concentrations of a contaminant, the following equation is used (Travis and Arms, 1988): $\log B_{\mathrm{b}}=-7.6+\log K_{\mathrm{OW}}$, in which $B_{\mathrm{b}}$ is the biotransfer factor in beef of that particular contaminant. Using these BTF equations, the following BTFs would be expected: in plants, for RDX 12.2 and for HMX 27.5-35.5; in worms, for RDX and HMX $10^{-7}$. The average BCF values found by us differed for plants by a factor of 2-20 for RDX and HMX, and for worms by a factor of $10^{7}$ for RDX from the calculated BTFs. The non-detectable HMX level in worms of the current study was in agreement with the calculated range, which is lower than the lowest explosives (metabolite) detection level attained by us $(>1.1 \mathrm{mg}$ $\mathrm{kg}^{-1}$ ). The discrepancies between BCFs and BTFs may indicate that predictions of tissue explosives levels in

Table 3

Tissue concentrations of explosives parent compounds, in $\mathrm{mg} \mathrm{kg}^{-1} \mathrm{DW}$, and bioconcentration factors (BCFs) in plants and worms

\begin{tabular}{|c|c|c|c|c|c|}
\hline \multirow[t]{3}{*}{ Soil-RDX (mg kg $\left.{ }^{-1} \mathrm{DW}\right)$} & \multicolumn{5}{|c|}{ Tissue explosives concentration and (BCF) } \\
\hline & \multicolumn{2}{|l|}{ L. perenne } & \multicolumn{2}{|l|}{ M. sativa } & \multirow{2}{*}{$\begin{array}{l}\text { E. fetida } \\
\text { RDX }\end{array}$} \\
\hline & RDX & HMX & RDX & HMX & \\
\hline $14 \mathrm{mg}$ & $806(58)$ & $<7.5$ & $187(134)$ & $16(162)$ & $<2.1(0)$ \\
\hline $645 \mathrm{mg}$ & $2055(3)$ & $26(3)$ & 3997 (6) & $65(7)$ & $41(0)$ \\
\hline $856 \mathrm{mg}$ & $3886(5)$ & $50(3)$ & $4355(5)$ & $84(5)$ & $1698(2)$ \\
\hline $1540 \mathrm{mg}$ & 3068 (2) & $43(1)$ & $4155(3)$ & $66(2)$ & $3268(2)$ \\
\hline Overall mean & 2454 (17) & $30(2)$ & 3594 (37) & $58(44)$ & $1251(1)$ \\
\hline
\end{tabular}

Mean values of three replicates. 
plants and worms solely based on specific $K_{\mathrm{OW}} \mathrm{s}$ may give erroneous results for organisms experiencing prolonged exposure to soil-based explosives because of metabolic, transport, and equilibrium processes inside the organisms themselves.

\section{Conclusions}

This study provides data that can be used to predict exposure-based effects of RDX in aged soil on two plant and two worm species. These data can be used for defining criteria or reference values for environmental management. No screening benchmark for RDX in soil for plants was found, since concentrations up to $1540 \mathrm{mg}$ $\mathrm{kg}^{-1}$ soil failed to reduce biomass by $20 \%$. RDX, RDX-metabolite MNX, and accompanying HMX concentrations in plants were significantly related to concentrations in soil after 55-day of exposure. The average BCFs in plants were $17-37$ for RDX, and 2-44 for HMX in plants. A LOEC of $1253 \mathrm{mg} \mathrm{kg}^{-1}$ soil-DW was estimated for RDX in the earthworm $E$. fetida. RDX concentrations in E. fetida were significantly related to concentrations in soil after 28-day exposure. The average BCF in E. fetida for RDX was 1 . Because in response to exposure to RDX-contaminated soil the RDX concentrations in plants increased initially and decreased subsequently, while those in worms increased continuously, RDX in worm tissues may accumulate to higher concentrations than in plant tissues, regardless of the low average BCF for worms.

\section{Acknowledgments}

This research was funded by the US Army Corps of Engineers Environmental Quality Technology Program. The work reported here was part of the Army Environmental Research and Development Center's 'Bioavailability, uptake, toxicity, and transfer across trophic levels of TNT and RDX in aged soil' Project. Ms. Margaret Richmond (Analytical Services Inc.) is gratefully acknowledged for technical assistance.

\section{References}

ASTM, 1998. Standard guide for conducting laboratory soil toxicity or bioaccumulation tests with the Lumbricid earthworm Eisenia fetida. E-1976-97. American Society for Testing and Materials, West Conshoshocken, Pennsylvania.

ASTM, 1999. Standard Guide for Conducting Terrestrial Plant Toxicity Tests. E-1963-98, American Society for Testing and Materials, Philadelphia, Pennsylvania.

ATSDR (Agency for Toxic Substances and Disease Registry), 1995. Toxicological profile for RDX. Public Health Service,
US Department of Health and Human Services, Washington, DC.

Best, E.P.H., Jacobs, F.H.H., 2001. Production, nutrient availability, and elemental balances of two meadows affected by different fertilization and water table regimes. Plant Ecology 55, 61-73.

Best, E.P.H., Sprecher, S.L., Larson, S., Fredrickson, H.L., Bader, D.F., 1999. Environmental behavior of explosives in groundwater from the Milan Army Ammunition Plant in aquatic and wetland plant treatments. Uptake and fate of TNT and RDX in plants. Chemosphere 39, 2057-2072.

Best, E.P.H., Tatem, H.E., Geter, K.N., Wells, M.L., Lane, B.K., 2004a. Toxicity and metabolites of 2,4,6-trinitrotoluene (TNT) in plants and worms from exposure to aged soil. ERDC/EL TR-04-18, US Army Engineer Research and Development Center, Vicksburg, Mississippi, January 2004.

Best, E.P.H., Tatem, H.E., Wells, M.L., Geter, K.N., Lane, B.K., 2004b. Toxicity and residues of aged TNT in plants and worms. In: Alleman, B., Downes, S., Battelle (Eds.), Proceedings of the Conference on Sustainable Range Management, New Orleans, Louisiana; January 5-8, 2004. CD Proceedings; ISBN 1-57477-144-2.

Gorsuch, J.W., Kringle, R.O., Robillard, K.A., 1990. Chemical effects on the germination and early growth of terrestrial plants. In: Wang, W., Gorsuch, J.W., Lower, W.R. (Eds.), Plants for Toxicity Assessment. American Society for Testing and Materials, Philadelphia, Pennsylvania.

Harvey, S.D., Fellows, R.J., Cataldo, D.A., Bean, R.M., 1991. Fate of the explosive hexahydro-1,3,5-trinitro-1,3,5-triazine (RDX) in soil and bioaccumulation in bush bean hydroponic plants. Environmental Toxicology and Chemistry 10, $845-855$.

ICF, 1989. Scoping study of the effects of sol contamination on terrestrial biota. Prepared for Office of Toxic Substances, USEPA, Washington, DC.

Kula, H., Larink, O., 1998. Tests on the Earthworms Eisenia fetida and Aporrectodea caliginosa. In: Lokke, H., Van Gestel, C.A.M. (Eds.), Handbook of Soil Invertebrate Toxicity Tests. John Wiley, New York, USA, pp. 95-112 (Chapter 7).

Lokke, H., Van Gestel, C.A.M., 1998. Soil toxicity tests in risk assessment of new and existing chemicals. In: Lokke, H., Van Gestel, C.A.M. (Eds.), Handbook of Soil Invertebrate Toxicity Tests. John Wiley \& Sons, Chichester, New York, Weinheim, Brisbane, Singapore, Toronto, pp. 3-19.

Malmberg, M., Allard, A.S., Remberger, M., 1998. Utveckling av biologiska metoder for bedomning av fororenad mark. IVL Svenska Milo Institutet AB Rapport B 1294 (In Swedish, English summary).

Markwiese, J.T., Ryti, R.T., Hooten, M.M., Michael, D.I., Hlohowskyj, I., 2000. Toxicity bioassays for ecological risk assessment in arid and semiarid ecosystems. Review in Environmental and Contaminant Toxicology 168, 43-98.

McNamara, B.P., Averill, H.P., Owens, E.J., 1974. The toxicology of cyclotrimethylene-trinitramine (RDX) and cyclotetra-methylenetetranitramine (HMX) solutions in dimethylsulfoxide (DMSO), cyclohexanone, and acetone. AD-780010. US Army, Aberdeen Proving Ground, MD.

OECD (Organization for Economic Cooperation and Development), 1984. Terrestrial plants, growth test. In: Guideline of the OECD for testing chemical products. OECD, Paris. 
Phillips, C.T., Checkai, R.T., Wentsel, R.S., 1993. Toxicity of selected munitions and munition-contaminated soil on the earthworm (Eisenia foetida). AD-A264408 Edgewood Research DEC, Aberdeen proving Ground, MD.

Price, R.A., Pennington, J.C., Larson, S.L., Neumann, D., Hayes, C.A., 2002. Uptake of RDX and TNT by agronomic plants. Soil and Sediment Contamination 11, 307-326.

Renoux, A.Y., Caumartin, J., Thiboutot, S., Ampleman, G., Sunahara, G.I., 2001. Derivation of environmental soil quality guidelines for 2,4,6-trinitrotoluene in soil using the CCME approach. Human and Ecological Risk Assessment 7, 1715-1735.

Robidoux, P.Y., Hawari, J., Thiboutot, S., Sunahara, G.I., 2002a. Ecological risk assessment of explosives contaminated sites. In: Renoux, A.Y., Gaudet, C.L., Thelen, C., Pilon, A. (Eds.), Environmental Analysis of Contaminated Sites. Wiley, UK, pp. 335-359.

Robidoux, P.Y., Hawari, J., Bardai, G., Paquet, L., Ampleman, G., Thiboutot, S., Sunahara, G.I., 2002b. TNT, RDX, and HMX decrease earthworm (Eisenia andrei) life cycle responses in a spiked natural forest soil. Archives of Environmental Contamination and Toxicology 43, 379-388.

Robidoux, P.Y., Bardai, G., Paquet, L., Ampleman, G., Thiboutot, S., Hawari, J., Sunahara, G.I., 2003. Phytotoxicity of 2,4 6-trinitrotoluene (TNT) and octa-hydro-1,3,5,7tetranitro-1,3,5,7-tetrazocine (HMX) in spiked artificial and natural forest soils. Archives of Environmental Contamination and Toxicology 44, 198-209.

Shaw Environmental, 2003. Picatinny Arsenal Task Order 17, Phase III 2A/3A Sites Remedial Investigation Report, vol. 2 -Area L Sites. Draft Final, September 2003.
Simini, M., Wentsel, R.S., Checkai, R.T., Phillips, C.T., Chester, N.A., Major, M.A., Amos, J.C., 1995. Evaluation of soil toxicity at Joliet Army Ammunition Plant. Environmental Toxicology and Chemistry 14, 623-630.

Talmage, S.S., Opresko, D.M., Maxwell, C.J., Welsh, C.J.E., Cretella, F.M., Reno, P.H., Daniel, F.B., 1999. Nitroaromatic munition compounds: environmental effects and screening values. Reviews in Environmental and Contaminant Toxicology 161, 1-156.

Travis, C.C., Arms, A.D., 1988. Bioconcentration of organics in beef, milk, and vegetation. Environmental Science and Technology 22, 217-274.

USEPA, 1992. US Environmental Protection Agency, Test Methods for Evaluating Solid Wastes, Proposed Update II, Method 8330. Rep. SW-846, third ed. Office of Solid Waste and Emergency Response, Washington, DC, USA.

USEPA, 1996. US Environmental Protection Agency, Ecological Effects Test Guidelines. OPPTS 850.4800. Plant Uptake and Translocation Test. EPA 712-C-96-159. April 1996.

USEPA, 1999. US Environmental Protection Agency, Office of Solid Waste, Washington D.C. Data Collection for the Hazardous Waste Identification Rule. Section 14.0 Ecological Benchmarks. Prepared by: Center for Environmental Analysis, Research Triangle Institute, 3040 Cornwallis Road, Research Triangle Park, NC 27709-2194, Under Contract No. 68-W-98-08.

Van de Leemkuile, M.A., Van Hesteren, S., Pruiksma, M.A., 1998. Minimal soil quality: A useage oriented approach from ecology. Part 2. Immobile organic contaminants. Technical Committee Soil Protection, The Hague, The Netherlands. TCB R09 (1998). 107 p. (in Dutch). 